УДК 631.4/.8:631.527.5:633.15

(C) 2016

Срмакова Л. М., кандидат сільськогосподарських наук, Крестьянінов $\epsilon$. В., здобувач

(науковий керівник - кандидат сільськогосподарських наук Л. М. Срмакова)

Національний університет біоресурсів і природокористування України

\title{
УРОЖАЙНІСТЬ КУКУРУДЗИ ЗАЛЕЖНО ВІД УДОБРЕННЯ ТА ГІБРИДУ НА ТЕМНО-СІРИХ ОПІДЗОЛЕНИХ ГРУНТАХ
}

\section{Рецензент - доктор сільськогосподарських наук Г. М. Ковалишина}

У статті наведено результати досліджень щчодо впливу позакореневого підживлення посівів кукурудзи водорозчинним добривом «Нутрімікс», «Нутрібор» $i$ «Мікро-Мінераліс» на фоні розрахункової норми повного мінерального добрива $N_{158} P_{52} K_{52}$ (фон) на урожайність та якість зерна кукурудзи. Встановлено, щзо застосування позакореневого підживлення на фоні основного удобрення має позитивний вплив на продуктивність досліджуваних гібридів кукурудзи. На основі аналізу результатів досліджень виявлено, щзо оптимізація живлення сприяє більш повному розкриттю ресурсного потенціалу рослин та підвищенню врожайності.

Ключові слова: кукурудза, гібрид, мікродобриво, урожайність, продуктивність.

Постановка проблеми. У світовому землеробстві кукурудзі належить провідна роль. Поряд із пшеницею та рисом вона відноситься до трьох головних зернових культур світу та зайняла пріоритетне місце серед них за площами посіву та обсягами виробництва зерна. За потенціалом продуктивності кукурудза займає перше місце серед зернових культур. Протягом останніх п’яти років найбільший валовий збір зерна кукурудзи було отримано у 2013 році (32 млн т зерна), а середня урожайність по Україні досягла 6,4 т/га [1]. Зважаючи на високий потенціал продуктивності сучасних гібридів кукурудзи та середню урожайність по Україні, можна зробити висновок, що спостерігається низька реалізація потенціалу продуктивності культури. Успіх у вирішенні цієї проблеми головним чином залежить від оптимізації живлення та застосування мікродобрив нового покоління для позакореневого підживлення посівів.

На даному етапі розвитку інтенсифікації землеробства одним зі способів підвищення врожайності сільськогосподарських культур є застосування мікродобрив та підживлення рослин ними, особливо тих, що містять необхідні мікроелементи відповідно до потреби рослин у формі хелатів [3].

Рослини кукурудзи засвоюють значну кількість мікроелементів і досить чутливі до їх нестачі на певних етапах росту і розвитку. 3 метою забезпечення рослин кукурудзи марганцем, цинком, молібденом та сіркою застосовують велику кількість мікродобрив. Одними з таких є добрива «Нутрібор» $\mathrm{i}$ «Нутрімікс».

Добриво «Нутрімікс» спеціально розроблене для збалансованого підживлення в першу чергу зернових культур та кукурудзи зокрема. Добриво для листкового підживлення «Нутрімікс» $\epsilon$ повністю водорозчинним добривом 3 мікроелементами $з$ особливим акцентом на $\mathrm{Mn}(4 \%), \mathrm{Zn}$ (3 \%) і $\mathrm{Cu}(4 \%)$ та Молібден $(0,04 \%)$. Окрім зазначених мікроелементів добриво в своєму складі містить $15 \%$ сірки та $8 \%$ азоту.

«Нутрібор»- це водорозчинне добриво 3 переважаючими мікроелементами: марганець, цинк, магній, молібден і бор. Добриво містить $12 \%$ сірки та $6 \%$ азоту. Основним елементом у зазначеному добриві $є$ бор, вміст якого становить $8 \%$.

Ці добрива мають цілу низку переваг порівняно з іншими. В першу чергу це стосується доброї їх сумісності з препаратами для захисту рослин від шкодочинних об'єктів. За результатами цілої низки випробувань у господарствах України та країн світу встановлено високу ефективність добрив «Нутрімікс» та «Нутрібор», які забезпечують зростання врожайності та покращання якості зерна. Не менш важливим є ефективність застосування добрив в умовах стресових ситуацій, які посилилися завдяки змінам погодно-кліматичних умов. Згідно з рекомендаціями найвищий ефект добрива забезпечують у разі застосування їх у підживленні по вегетуючих рослинах [2]. 


\section{СІЛЬСЬКЕ ГОСПОДАРСТВО. РОСЛИННИЦТВО}

Аналіз останніх досліджень і публікацій, у яких започатковано розв'язання проблеми. У сучасних технологіях вирощування сільськогосподарських культур одним із важливих елементів є позакореневе підживлення, яке суттєво підвищує урожайність та покращує якість отриманої продукції за рахунок збалансованого та швидкого забезпечення потреб рослин в елементах живлення саме в ті періоди росту та розвитку, коли вони найбільше їх потребують.

Для позакореневого підживлення використовують мікроелементні добрива, асортимент яких щорічно зростає. Ефективність їх у технологіях вирощування сільськогосподарських культур досить висока незалежно від способу їх використання (обробка насіння чи листкове підживлення). Це обгрунтовано цілою низкою наукових досліджень та обумовлено тим, що приріст урожайності і покращання якості продукції значно вищі порівняно зі зростанням виробничих витрат на 1 га посіву. Так, економічна окупність кожної додатково витраченої гривні на використання мікродобрив залежно від культури коливається в межах від 4,5 до 9 гривень та найвищу окупність забезпечує кукурудза (9 грн).

Кукурудза є однією з провідних зернових культур світу та України завдяки високому потенціалу продуктивності (14-15 т/га) порівняно 3 іншими зерновими культурами. Проте не завжди досягається реалізація потенційних можливостей гібридів кукурудзи. Це пов’язано, насамперед, 3 біологічними особливостями культури та потребою іiі на певних етапах органогенезу в забезпеченні як макро-, так і мікроелементами.

Мета дослідження - виявити особливості росту та розвитку рослин, формування врожайності сучасних гібридів кукурудзи залежно від фону мінерального живлення та позакореневого підживлення посівів мікродобривами нового покоління «Нутрібор», «Нутрімікс» і «МікроМінераліс».

Матеріали і методика досліджень. Дослідження проводилися протягом 2015-2016 рр. на темно-сірих опідзолених легкосуглинкових грунтах Лівобережного Лісостепу України (ТОВ «Українська молочна компанія», с. Великий Крупіль Згурівського району Київської області). Попередником кукурудзи в досліді була соя. Пі- сля обробітку грунту проводили підготовку поля за схемою досліду до внесення мінеральних добрив. В основний обробіток грунту вносили діамофос NPK 10:26:26 200 кг ф.в. на 1 га. Передпосівний обробіток грунту включав ранньовесняне боронування, дві глибокі культивації на 810 см. За сім днів до сівби під культивацію вносили карбамід у нормі 300 кг ф.в. ( $\mathrm{N}_{138}$ д.р.). Сівбу проводили, коли грунт на глибині загортання насіння прогрівся до 8-10 ${ }^{\circ} \mathrm{C}$, гібридами Оржиця 238 MB та Аякс. Після сівби поле коткувалося.

Метеорологічні умови років досліджень були мінливими, що дало змогу всебічно і об'єктивно оцінити досліджувані гібриди залежно від метеорологічних чинників та агротехнічних прийомів вирощування.

Варіанти досліду включали обробляння посівів кукурудзи добривом «Нутрімікс» (1 л/га) + «Нутрібор» (0,5 л/га) у фазу 4 листків, 8-ми листків та «Мікро-Мінераліс (Кукурудза)» 1 л/га у зазначені фази. Разом $з$ тим проводилася однота дворазова обробка посівів у фази 4-го та 8-го листків і сумісне внесення всіх трьох видів мікродобрив.

Результати досліджень. Інтегральним показником ефективності вирощування будь-якої культури є іï урожайність. Встановлено, що найбільшу урожайність було сформовано посівами гібриду кукурудзи Аякс у 2016 році, яка становила 10,3 т/га (див. табл.), що перевищило контроль без підживлення на 0,7 т/га за варіанту внесення по вегетуючих рослинах добрива «Нутрімікс» $(1$ т/га $)+$ «Нутрібор» $(0,5$ кг/га) з мікродобривом «Мікро-Мінераліс (Кукурудза)» (1 л/га) по 4 та 8 листку на фоні розрахункової норми мінеральних добрив.

Висновок. У процесі досліджень виявлена висока ефективність застосування добрив «Нутрімікс» та «Нутрібор» у зазначених нормах внесення за дворазової обробки посівів. Урожайність на даному варіанті становила відповідно у 20152016 pp. 9,9 та 9,3 т/га. Ефективність застосування добрива «Мікро-Мінераліс (Кукурудза)» була меншою порівняно 3 добривами «Нутрімікс» та «Нутрібор» на 0,4-1,0 т/га. Отже, більш високий ефект отримано від комплексного застосування мікродобрив та дворазової обробки посівів протягом вегетаційного періоду кукурудзи. 
СІЛЬСЬКЕ ГОСПОДАРСТВО. РОСЛИННИЦТВО

Урожайність кукурудзи залежно від удобрення та гібриду, $m / 2 a$

\begin{tabular}{|c|c|c|c|c|}
\hline \multirow{2}{*}{ Гібрид } & \multirow{2}{*}{\multicolumn{2}{|c|}{ Варіант удобрення }} & \multicolumn{2}{|c|}{ Урожайність, т/га } \\
\hline & & & $2015 \mathrm{p}$. & $2016 \mathrm{p}$. \\
\hline \multirow{8}{*}{ 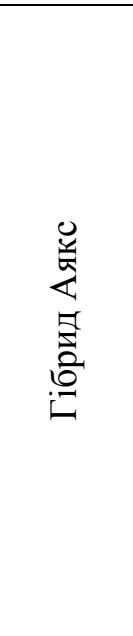 } & 1 & Фон $\mathrm{N}_{158} \mathrm{P}_{52} \mathrm{~K}_{52}$ - контроль без підживлення & 8,6 & 9,5 \\
\hline & 2 & Фон + «Нутрімікс» (1 кг/га), «Нутрібор» $(0,5$ кг/га) по 4 листку & 8,82 & 9,67 \\
\hline & 3 & Фон + «Нутрімікс» (1 кг/га), «Нутрібор» $(0,5$ кг/га) по 8 листку & 8,85 & 9,71 \\
\hline & 4 & $\begin{array}{l}\text { Фон + «Нутрімікс» }(1 \text { кг/га), «Нутрібор» }(0,5 \text { кг/га) по } 4 \text { листку; } \\
\text { Фон + «Нутрімікс» }(1 \text { кг/га), «Нутрібор» }(0,5 \text { кг/га) по } 8 \text { листку }\end{array}$ & 9,27 & 9,92 \\
\hline & 5 & Фон + «Мікро-Мінераліс (Кукурудза)» (1 л/га) по 4 листку & 8,62 & 9,59 \\
\hline & 6 & Фон + «Мікро-Мінераліс (Кукурудза)» (1 л/га) по 8 листку & 8,65 & 9,67 \\
\hline & 7 & 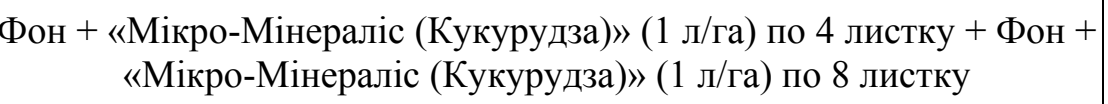 & 8,87 & 9,79 \\
\hline & 8 & $\begin{array}{c}\text { Фон + «Нутрімікс» }(1 \text { кг/га), «Нутрібор» }(0,5 \text { кг/га) «Мікро- } \\
\text { Мінераліс (Кукурудза)» (1 л/га) по } 4 \text { листку + «Нутрімікс» } \\
\text { (1 кг/га), «Нутрібор» (0,5 кг/га), «Мікро-Мінераліс (Кукурудза)» } \\
\text { (1 л/га) по } 8 \text { листку }\end{array}$ & 9,45 & 10,30 \\
\hline \multirow{8}{*}{ 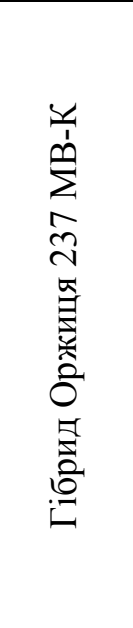 } & 1 & Фон $\mathrm{N}_{158} \mathrm{P}_{52} \mathrm{~K}_{52}$ - контроль без підживлення & 7,95 & 9,01 \\
\hline & 2 & Фон + «Нутрімікс» (1 кг/га), «Нутрібор» $(0,5$ кг/га) по 4 листку & 8,17 & 9,28 \\
\hline & 3 & Фон + «Нутрімікс» (1 кг/га), «Нутрібор» $(0,5$ кг/га) по 8 листку & 8,23 & 9,31 \\
\hline & 4 & $\begin{array}{l}\text { Фон + «Нутрімікс» }(1 \text { кг/га), «Нутрібор» }(0,5 \text { кг/га) по } 4 \text { листку; } \\
\text { Фон + «Нутрімікс» }(1 \text { кг/га), «Нутрібор» }(0,5 \text { кг/га) по } 8 \text { листку }\end{array}$ & 8,59 & 9,35 \\
\hline & 5 & Фон + «Мікро-Мінераліс (Кукурудза)» (1 л/га) по 4 листку & 8,06 & 9,13 \\
\hline & 6 & Фон + «Мікро-Мінераліс (Кукурудза)» (1 л/га) по 8 листку & 8,12 & 9,19 \\
\hline & 7 & $\begin{array}{c}\text { Фон + «Мікро-Мінераліс (Кукурудза)» }(1 \text { л/га) по } 4 \text { листку + Фон + } \\
\text { «Мікро-Мінераліс (Кукурудза)» }(1 \text { л/га) по } 8 \text { листку }\end{array}$ & 8,46 & 9,27 \\
\hline & 8 & $\begin{array}{c}\text { Фон + «Нутрімікс» }(1 \text { кг/га), «Нутрібор» }(0,5 \text { кг/га), «Мікро- } \\
\text { Мінераліс (Кукурудза)» (1 л/га) по } 4 \text { листку + «Нутрімікс» } \\
\text { (1 кг/га), «Нутрібор» (0,5 кг/га), «Мікро-Мінераліс (Кукурудза)» } \\
(1 \text { л/га) по } 8 \text { листку }\end{array}$ & 8,89 & 9,59 \\
\hline
\end{tabular}

\section{БІБЛІОГРАФІЯ}

1. Грибнич В. Н., Партас Е. К. Изучение генетического разнообразия самоопыленных линий кукурудзы / В. Н. Грибнич, Е. К. Партас // Генетика, селекция и технология возделывания кукурудзы. - Майкоп : РИПО Адыгея, 1999. - С. 152156.

2. Плотніков В. В. Звіт про результати випробувань рідкого органічного добрива - стимулятора росту рослин Вітазим виробництва фірми «Вітал ЕЧ Ресурс», США, в демонстраційних дослідах Вінницької ДСГДС Інституту кормів

УААН. - Вінниця : Вінницька державна сільськогосподарська дослідна станція Інституту кормів УААН, 2009.

3. Пономаренко С. П. Створення та впровадження нових регуляторів росту рослин в агропромисловому комплексі України : зб. наук. праць // Ефективність хімічних засобів у підвищенні продуктивності сільськогосподарських культур. - Умань : Уманська державна аграрна академія, 2001. - С. 15-23. 